\title{
АНТРОПОМОРФНЫЕ ИЗОБРАЖЕНИЯ УРАЛА В КАМНЕ, ГЛИНЕ И ГРАВИРОВКАХ
}

\author{
(C) 2021 Ю.Б. Сериков
}

\author{
Российский государственный профессионально-педагогический университет \\ (филиал в Нижнем Тагиле)
}

Статья поступила в редакцию 29.09.2021

\begin{abstract}
Деревянной скульптуре Урала, несмотря на ее редкость, посвящены многочисленные публикации и научные исследования. Менее известны антропоморфные скульптуры из камня, глины, а также гравированные антропоморфные изображения. В настоящее время в литературе описано около 400 изображений живых существ, обнаруженных на территории Урала и прилегающего к нему Зауралья, датируемых во временном диапазоне от палеолита до бронзового века. Антропоморфные изображения представлены 60 изделиями, что составляет всего $15 \%$ от общего числа. Каменные антропоморфные изображения условно можно подразделить на круглую, плоскую и кремневую скульптуру. Любопытны подвески, изготовленные в виде головы человека. Глиняные фигурки представлены изображениями женщин и отдельных голов. Редкими находками являются гравированные антропоморфные изображения, выполненные на камне и кости. Отдельную группу составляют изображения антропоморфных фигур на керамических сосудах. Бо́льшая часть скульптурных и графических изображений датируется неолитом - энеолитом.

Ключевые слова: Урал, каменный век, бронзовый век, антропоморфные изображения, камень, глина, кость, гравировки.
\end{abstract}

DOI: $10.37313 / 2658-4816-2021-3-4-90-101$

\author{
Список сокращений \\ М. - Москва \\ МГУ - Московский государственный университет \\ МИА - Материалы и исследования по археологии СССР \\ НТГСПА - Нижнетагильская государственная социально-педагогическая академия \\ ОмГПУ - Омский государственный педагогический университет \\ РАН - Российская Академия Наук \\ СПб. - Санкт-Петербург \\ СПбГУ - Санкт-Петербургский государственный университет \\ УрГУ - Уральский государственный университет \\ УрО РАН - Уральское отделение РАН
}

Самым ранним антропоморфным изображением Урала на территории Урала можно считать природную скульптуру со стоянки Лабазы I (Оренбургская обл.), возраст которой достигает 40 тыс. лет. Изделие из «катушки» эпифиза плечевой кости благородного оленя В.Г. Котов рассматривает в качестве антропоморфной скульптуры. Его

Сериков Юрий Борисович, доктор исторических наук, профессор, ведущий научный сотрудник. E-mail: u.b.serikov@mail.ru размеры $-6,4 \times 5 \times 5$ см. Отсечение лишних частей кости позволило выделить голову, руки и женскую грудь. Ноги обозначены гравировкой (рис. 1, 7). Данную находку В.Г. Котов сравнивает с антропоморфными статуэтками из Авдеево и Пршедмости и относит ее к «знаковой» скульптуре ${ }^{1}$.

К эпохе мезолита также относится единичная находка. Это вкладышевый наконечник стрелы эпохи мезолита длиной около 20 см, найденный в пещерном святилище 

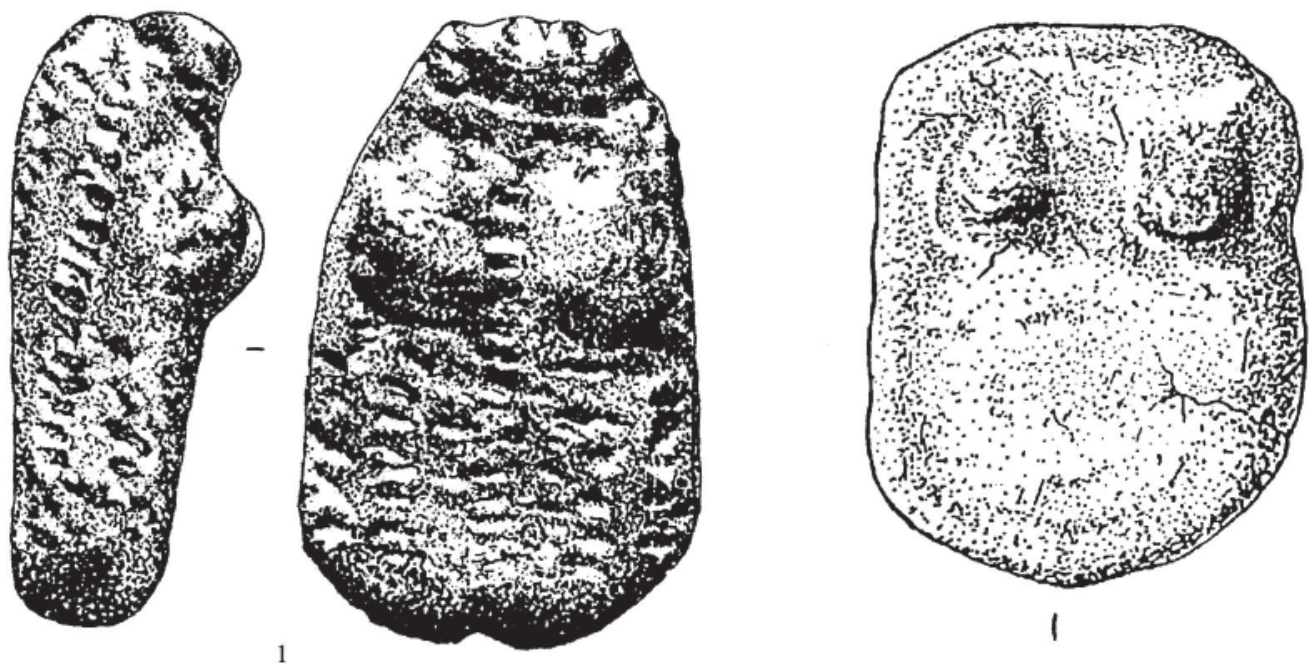

1
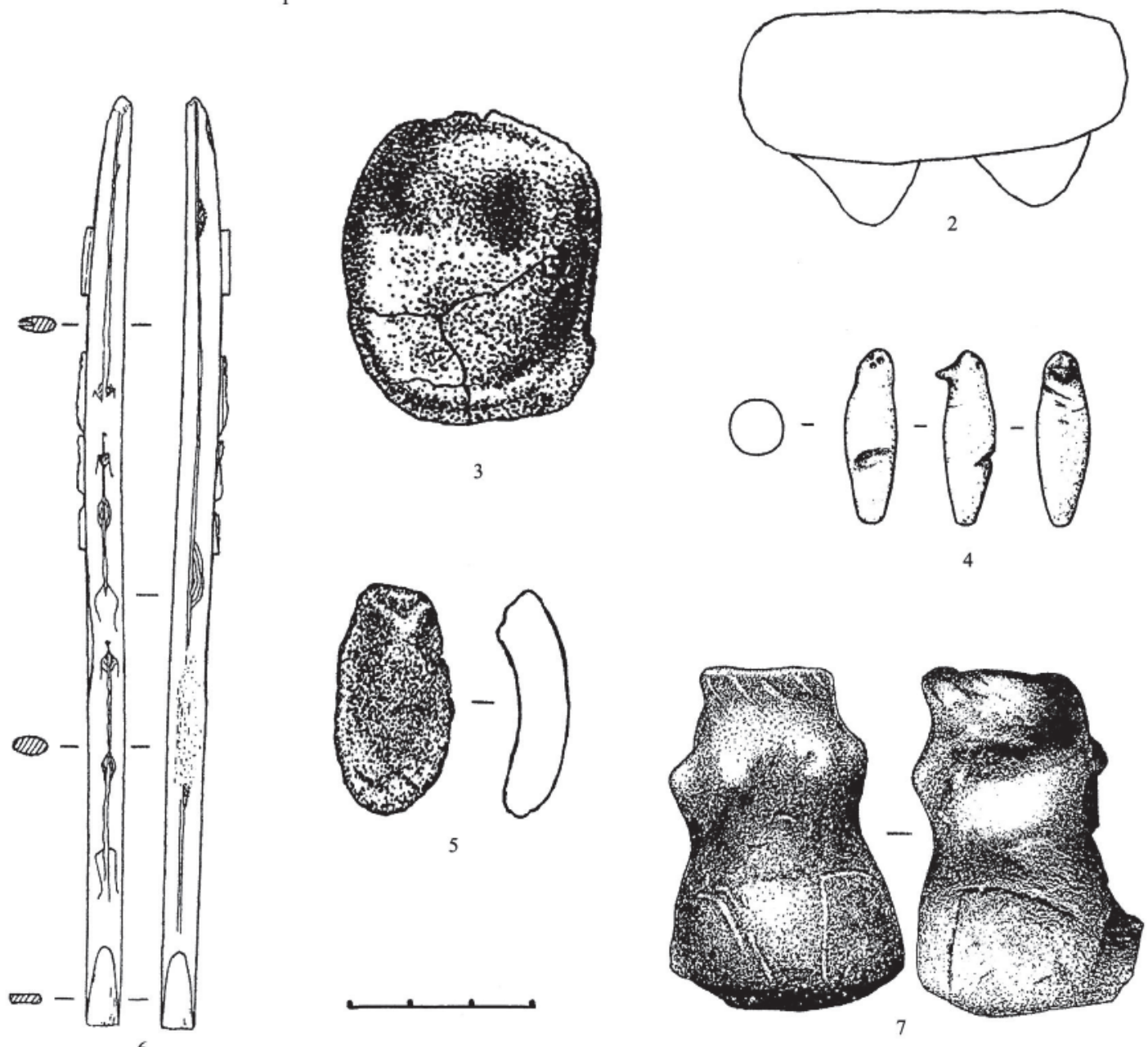

Рис. 1. Антропоморфные изображения из глины (1-5) и кости (6-7)

(1 - Березовый мыс; 2-3 - Палатки II; 4 - Усть-Вагильский холм; 5 - Кокшаровское Поле; 6 - Камень Дыроватый; 7 - Лабазы I)

на камне Дыроватом (р. Чусовая, Свердловская обл.). На одной из его сторон нанесены изображения двух антропоморфных фигур, расположенных одна под другой. Поскольку изобразительным полем является узкая плоскость наконечника стрелы, фигуры сильно заужены. Маленькая головка изображена короткими насечками, прямые руки опущены вниз, грудная клетка показана в скелетном стиле. Часть фигуры от груд- 
ной клетки до начала ног сильно удлинена и показана двумя параллельными линиями. Посередине предполагаемого туловища оно разделяется на две части округлым вздутием из скобчатых линий. Возможно, вздутый живот обозначает беременную женщину. Ноги показаны кривыми линиями. Линии, обозначающие туловище, выходят между ног в одном случае короткими отрезками, а в другом длинными и неодинаковыми. Что они изображают - непонятно. У верхней фигуры это могло быть изображением фаллоса, а у нижней - хвоста (рис. 1, 6). Как эти мужские символы совместить с женскими - остается загадкой. Необходимо добавить, что обе фигуры окрашены охройㄹ․

Остальные антропоморфные изображения датируются в широком хронологическом диапазоне от неолита до бронзового века. Изображения более поздних эпох в данной статье не рассматриваются.

Все каменные скульптуры условно можно разделить на объемные, плоские и кремневые.

Объемные антропоморфные скульптуры на Урале появляются в эпоху энеолита. Уникальным изделием является скульптура из талькохлорита, найденная на дне энеолитического жилища на поселении Палатки II (окраина г. Екатеринбург). Она изготовлена в виде стилизованного изображения человека (по С.Н. Паниной - человека-совы). Представляет собой брусок прямоугольных очертаний размером $27 \times 6,5 \times 2,8$ см. В верхней части бруска на его торцевой части вырезано лицо человека с массивным клювовидным носом. Вся остальная часть к изображению человека никакого отношения не имеет. На боковых поверхностях бруска по всей их длине вырезаны достаточно глубокие (до 0,5 см) прямые желобки, на одной плоскости - один, на противоположной - два. Обе торцевые грани орнаментированы перекрещивающимися гравированными линиями, образующими косые кресты, цепочка которых в свою очередь составляется в ромбы. На всех длинных ребрах бруска нанесены неглубокие насечки: с лицевой стороны по обоим ребрам суммарно - 21, с задней также суммарно - $28^{3}$ (рис. 1,1$)$.
Небольшая антропоморфная скульптура из плитки талька обнаружена в энеолитическом культовом центре Шайтанского озера I (Свердловская обл.). Ее высота 4,8 см, ширина - 2,1 см, толщина - 0,8-0,9 см. Голова отсутствует, плечи обработаны короткими срезами, ноги обозначены неглубокой прорезью, такими же вырезами показана талия (рис. 3,6 ). Лицевые и боковые плоскости изделия следов обработки не имеют ${ }^{4}$ В целом скульптура напоминает антропоморфные глиняные фигурки эпохи энеолита, найденные на памятниках Андреевского озера ${ }^{5}$. Любопытно заметить, что у всех глиняных статуэток еще в древности были отбиты головы.

На территории Урала известны еще антропоморфные скульптуры, которые использовались в качестве подвесок. В 2000 г. в Кумышанской пещере на р. Чусовой было исследовано необычное коллективное погребение, в котором находились останки трех женщин, двух новорожденных и двух плодов 7-9 месяцев. По костям человека погребение получило радиоуглеродную дату (калиброванную) - 3622-3108 Cal BC (СОАН-5155).

В могиле была найдена подвеска, выполненная в виде лица человека. Изготовлена подвеска в технике плоской скульптуры из зеленого офита - мягкой разновидности серпентинита. Ее высота 3 см, ширина 2,5 см, толщина 0,3 см. Скульптура тщательно отшлифована с двух сторон. Подвеска имеет овальную форму, с одной стороны рельефно подчеркнуты лоб, нос и подбородок. На месте глаза находится просверленное отверстие. В плане оно имеет форму треугольника с закругленными вершинами (рис. 2, 3). Поскольку офит- материал мягкий, ремешок, на котором крепилась подвеска, проточил его и превратил отверстие из круглого в подтреугольное. Проточенность в виде слабо выраженных канавок на обеих сторонах наблюдается и выше отверстия. Все это свидетельствует о долгом ношении подвески на ремешке .

Однако если подвеску подвесить на ниточку, то линия нитки не совпадет с направлением проточенного углубления. На лице- 

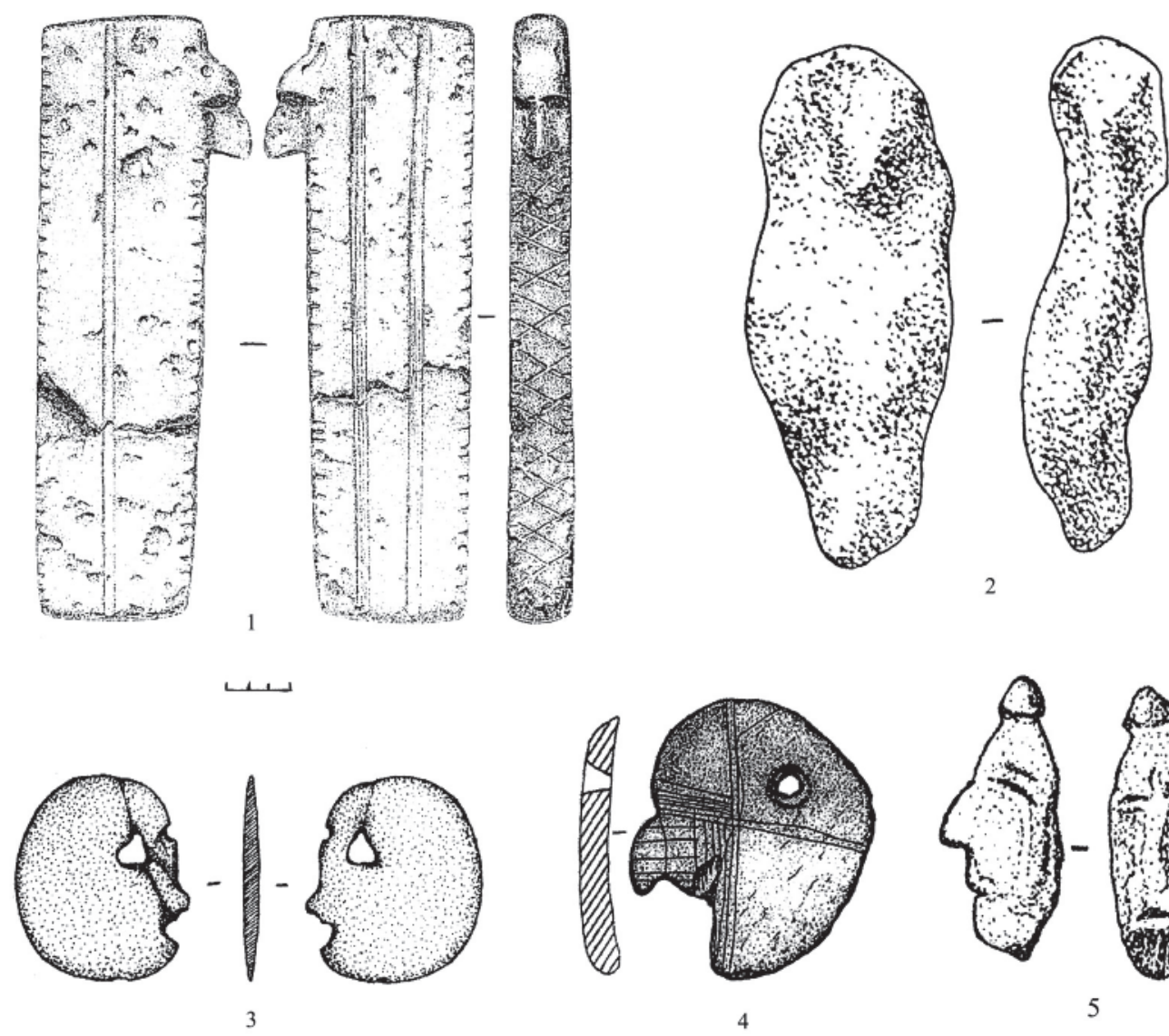

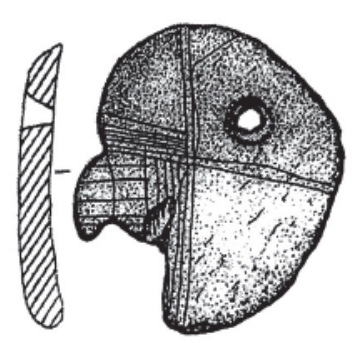

4

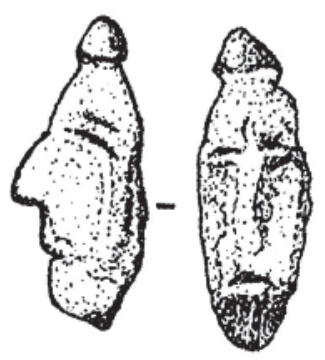

5
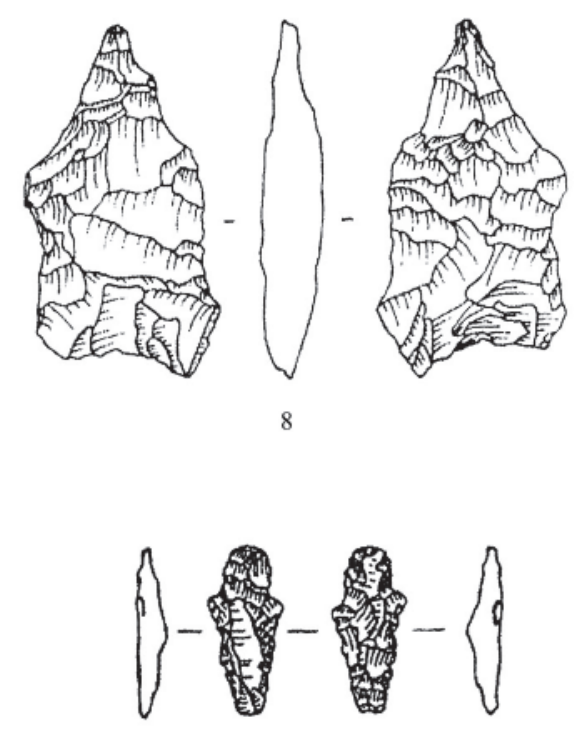
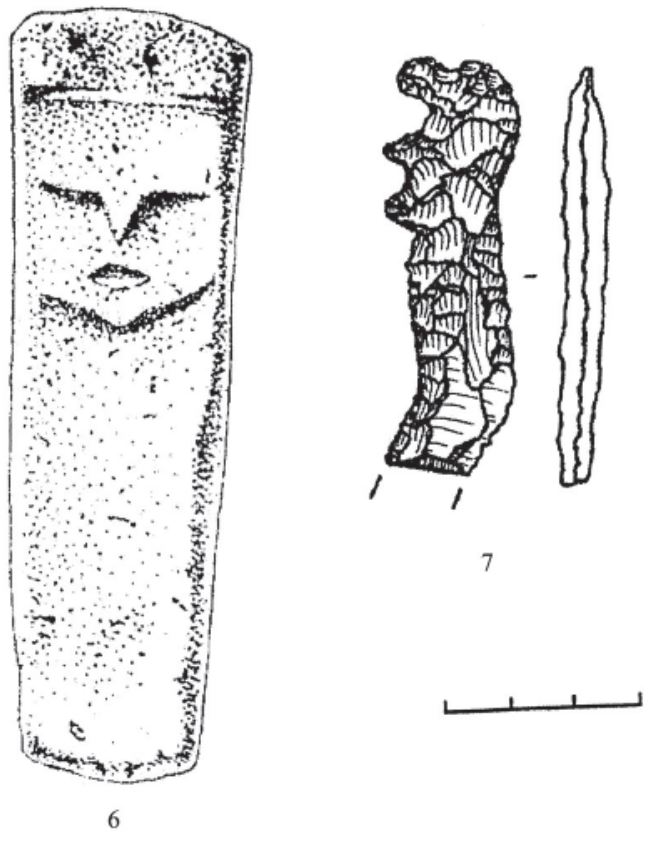

9

Рис. 2. Антропоморфные изображения из камня

(1 - Палатки II; 2 - Боровка III; 3 - Кумышанская пещера; 4 - Муллино;

5 - Усть-Кедва II; 6 - Сигаево III; 7 - Вис II; 8 - Шайтанское озеро I; 9 - Юрьино IV)

вой поверхности подвески присутствуют и другие проточенные канавки, которые идут от отверстия к носу, подбородку и лбу. Образовались эти потертости при ношении подвески от трения с пропущенными че- рез глаз (отверстие) к носу, подбородку и лбу нитями. Проточенности на оборотной стороне подвески отсутствуют. Это свидетельствует о том, что подвеска была прикреплена к какой-то основе и нити не со- 
прикасались непосредственно с оборотной стороной подвески. Можно предположить, что «лицо» было пришито к контуру человеческого тела, вырезанному из бересты или, скорее, кожи. Для проверки предположения подвеска была пришита к контурной фигурке человека длиной 13 см, вырезанной из кожи. При контрольном подвешивании проточенные канавки, идущие выше отверстия, совпали с линией натяжения нити. Это доказывает правильность нашего предположения.

Определяя сакральное назначение подвески, можно предположить, что, возможно, она служила итермой - вместилищем души предка. Этим предком мог быть и шаман. У юкагиров, например, череп умершего шамана приставляли к изображавшей его деревянной фигуре и покрывали шапкой. K лицевой части черепа прикрепляли маску с отверстиями для глаз и рта. На фигуру надевали одежды и сажали ее в переднем углу жилища ${ }^{7}$.

Подобная подвеска в виде плоского изображения лица человека обнаружена на энеолитическом поселении Муллино (Башкортостан) (рис. 2, 4). Она немного крупнее, ее высота 4 см, ширина 3,6 см. На подвеске также выделены лоб, нос и подбородок. Кроме этого пропилом показан разрез рта. В верхней части подвески (но не на месте глаза) просверлено отверстие для подвешивания

На размытом поселении Сигаево III (Челябинская обл.) найдена подвеска, изготовленная из плоской плитки талька длиной 6,5 см. В верхней ее части глубоким рельефом вырезано лицо человека9 (рис. 2, 6). Еще одна подвеска найдена в жилище эпохи бронзы поселения Усть-Кедва II (Республика Коми). Она имеет высоту 4,5 cм, также выполнена в виде лица человека, но уже в технике объемной скульптуры. Изображает она голову мужчины с островерхим головным убором (рис. 2,5). Для крепления использовалась круговая нарезка в верхней части скульптуры ${ }^{10}$.

Заключают коллекцию каменной скульптуры пять кремневых фигурок, изобража- ющих человека. Все они относятся к эпохе энеолита. Две из них выявлены на Северном Урале (Вис II и Сандибей-ю VIII), одна на Южном (Карабалыкты IX) и две на Среднем (Юрьино IV и Шайтанское озеро I) ${ }^{11}$. Все фигурки обладают своеобразными чертами, отличающими их от скульптур европейской части России. Антропоморфная скульптура с поселения Вис II Г.М. Буровым определена как млекопитающее ${ }^{12}$. Но В.Н. Карманов и B.А. Семенов видят в фигурке крайне редкое профильное изображение человека (рис. 2, 7). И сравнивают его со скульптурой со стоянки Ольский Мыс на оз. Лача ${ }^{13}$. Фигурка с Юрьино IV (Юрьинское озеро) имеет неразделенные ноги, что никогда не встречается в европейской России (рис. 2, 9). У скульптуры округлая голова, руки показаны слегка намеченными выступами, между головой и руками присутствуют слабовыраженные выемки - попытка мастера показать шею. Асимметричный профиль скульптурки, возможно, является попыткой показать живот или отвисшую грудь женщины. Высота фигурки 2,5 см, максимальная ширина $1,2 \mathrm{~cm}^{14}$. Изделие с Шайтанского озера, по-видимому, является незаконченной фигуркой человека (мифологического существа?). Оно имеет раздвоенное основание (ноги), боковые выступы посередине (руки) и вытянутую вверх голову (островерхая шапка) (рис. 2, 8) ${ }^{15}$.

Еще одна скульптура на основе природной формы найдена в очаге на энеолитической стоянке-мастерской Боровка III (Свердловская обл.). Это галька антропоморфной формы, которая изображает человеческую фигурку с прижатыми к телу руками и нерасчлененными ногами. Голова с выступающим вперед лицом показана естественными неровностями гальки (рис. $2,2)$. Учитывая место находки, а также тот факт, что подобного галечного сырья на памятнике больше не обнаружено, можно предположить, что такая необычная галька использовалась в качестве естественной антропоморфной скульптуры ${ }^{16}$.

Глиняные антропоморфные скульптуры на Урале появляются в неолитическую эпоху. 
На стоянке Кокшаровское Поле (Юрьинское озеро) на пахоте найдена глиняная эмбрионовидная фигурка высотой 3,6 см. Она овальная в плане и слегка изогнута в профиле. Ноги и руки у скульптуры не показаны. Лицо (нос и брови) моделировано пальцевыми защипами ${ }^{17}$ (рис. 1, 5). Это первая эмбрионовидная фигурка, найденная на территории Урала. В сравнении с известными эмбрионовидными скульптурами данная фигурка представляется наиболее примитивной. Поэтому предварительно данное изображение можно отнести к эпохе неолита.

Неолитические антропоморфные фигурки из глины известны как на Северном (стоянки Эньты I и Вад I), так и на Южном Урале (Сабакты III).

На стоянке Эньты I (окрестности Сыктывкара) в слое раннего неолита найдено три фрагментированные скульптуры. Они представляют зооантропоморфные изображения, у которых голова, нос и конечности образованы пальцевыми защипами ${ }^{10}$.

На стоянке Вад I в слое среднего неолита обнаружена миниатюрная головка человека, выполненная из глины. Она имеет достаточно правильную округлую форму диаметром около 1,7 см. Лицо моделировано пальцевыми вдавлениями (?). Достаточно рельефно выделены глаза, нос, и рот. Снизу головки находится небольшое углубление, образованное наколом ${ }^{10}$.

Имеются сведения о десятке сломанных глиняных фигурок с ранненеолитической стоянки Угдым Іа (Республика Коми), которые еще не опубликованы.

Объемная головка человека из глины, но уже отбитая, видимо, от полной скульптуры найдена на Южном Урале на неолитической стоянке Сабакты III. Она крупнее вышеописанных, ее размеры 4,2 × 3,5 × 2,7 см. У скульптуры небольшими углублениями показаны глаза и рот. Выступающий и высоко расположенный нос напоминает клюв хищной птицы. По затылку, шее и подбородку прочерчены тонкие вертикальные полосы, изображающие, по всей видимости, бороду и косу (?) $)^{18}$.
На территории Среднего Зауралья глиняные фигурки становятся известны с энеолита. Широко известна найденная еще в середине XX в. глиняная антропоморфная статуэтка с Березового мыса (Аятское озеро, Свердловская обл.). Это самая крупная антропоморфная скульптура на Урале. Даже без головы, отбитой еще в древности, ее высота составляет около 8 см. Скульптура изготовлена достаточно схематично, ноги и руки у нее отсутствуют, но отчетливо выделена грудь. Фигурка по всей поверхности орнаментирована овальными наколами, которые, по всей видимости, обозначают одежду (рис. 1, 1). В.М. Раушенбах считала, что скульптура изображает женщину в одежде с каймой ${ }^{19}$.

С эпохой энеолита С.Н. Панина связывает находки оригинальных антропоморфных изображений из глины, найденных на культовом памятнике Усть-Вагильский холм (р. Тавда, Свердловская обл.). Одна фигурка сохранилась целиком, ее высота 2,6 см. У второй отбита головка, сохранился фрагмент длиной 2 см. Нижняя ее часть была окрашена охрой. Фигурки представляют собой слегка заостренные книзу глиняные стерженьки круглого сечения. У целой фигурки защипом оформлен выступающий острый нос. В верхней части фигурка украшена резными линиями и ямочными вдавлениями ${ }^{20}$ (рис. 1, 4).

Две глиняные статуэтки найдены на поселении Палатки II (окрестности Екатеринбурга). Одна из них залегала в жилище бронзового века. Изготовлена она в виде бруска со скругленными углами без головы, рук и ног. Высота фигурки 7,5 см, ширина - 5,8 см, толщина - 2,4 см. Единственным определяющим признаком является рельефно вылепленная грудь ${ }^{21}$ (рис. 1, 2). Там же найдена еще одна женская фигурка из глины (поврежденная), которая является уменьшенной копией первой. У нее также отсутствуют голова, руки, ноги, но показана выпуклая грудь. Размеры изображения: 5,8 × 3,9 cм ${ }^{22}$ (рис. 1, 3).

Несомненно, показателем каких-то культовых действий является наличие в 
коллекции глиняной пластики фигурок с отбитыми головами, отбитых голов и скульптурных изображений голов. Головы отбиты у фигуры с Березового мыса, УстьВагильского холма и трех скульптур с Андреевского озера. Отбитая голова человека найдена только одна, на стоянке Сабакты III. Скульптурных изображений голов в коллекции две - со стоянок Вад I и ЮАО-XIII.

Автором уже высказывалось предположение, что на Урале в течение продолжительного времени существовал своеобразный «культ голов» ${ }^{23}$. Поэтому не исключено, что антропоморфные фигурки с отбитыми головами в культовом плане могут соотноситься с некоторыми погребениями эпохи энеолита. Погребение на Аятском озере совершено без головы. Голова была захоронена отдельно, в жилище. С отчлененной головой был погребен мужчина на поселении Дружный. Голова стояла теменем вверх, а шейные позвонки находились в сосуде. Череп погребенного в гроте у Каменного Кольца находился в центре могилы затылочным отверстием вверх. Отсутствует череп и в погребении из навеса Старичный Гребень. В одной из могил Кара-Якуповского могильника (погребение 5) был захоронен только череп. Он лежал теменем вниз в окружении нескольких каменных и костяной подвесок. Захоронение черепа было обнаружено Д.Н. Маминым-Сибиряком на 2-м Карасьем озере. Подобные погребения без голов или захоронения отдельных черепов известны и на смежных территориях ${ }^{24}$.

Данные о культе голов можно найти в этнографии обских угров. В.Н. Чернецов отмечает, что после похорон умершего у них очень часто сохраняются черепа. Объясняется это тем, что череп является самой важной частью скелета, так как именно в нем обитает главная возрождающаяся (четвертая) душа человека. Сохранение черепов особенно распространяется на покойников, являвшихся при жизни наиболее важными представителями данного рода ${ }^{25}$.

Уникальное изделие с гравировками обнаружено в окрестностях г. Нижнего Тагила у пос. Антоновский (Свердловская обл.) ${ }^{26}$. Оно найдено на склоне горы, где никаких следов археологического памятника не выявлено. Изделие в виде крупного диска имеет овальную форму, диаметр длинной оси $14 \mathrm{~cm}$, короткой - 11,8 см. Толщина диска 1,5 см (рис. 3,1$)$. Он изготовлен из мягкого хлоритизированного сланца. Все поверхности - лицевая, оборотная и ребро - тщательно отшлифованы. В центре изделия находится круглое отверстие диаметром 3,5 - 3,7 см. По боковым граням диска с двух сторон металлическим орудием прорезаны крупные насечки. На лицевой стороне в одном горизонтальном поясе с отверстием по обе его стороны нанесено по три насечки, в верхнем полукружии расположено 29 насечек, в нижнем - 20. На оборотной поверхности по обе стороны отверстия нанесено 4 и 3 насечки, в верхнем полукружии - 28, в нижнем - 26. На ребре изделия присутствует орнамент в виде зигзагообразной линии. Такая же зигзагообразная линия (только сдвоенная) нанесена и на оборотной стороне. Она идет по всему периметру диска вдоль орнаментированной насечками грани. Ниже зигзага, в центральной части плоскости располагается более сложный орнамент. Он состоит из тупых углов, соединенных между собой лучами. В одном месте, где лучи не соединяются, имеется разрыв. На вершине каждого угла (за исключением одного) присутствуют парные насечки. Таких углов всего двенадцать. Вокруг отверстия в вертикальной и горизонтальной плоскости нанесены длинные сдвоенные насечки.

На лицевой стороне изделия изображены два антропоморфных фантастических существа. Одно из них стоит, второе (по отношению к первому) лежит. У стоящего антропоморфа показаны голова, шея, руки, туловище, ноги и хвост. Голова состоит из ромба и двух углов под ним. Широкие плечи заканчиваются парными насечками, руки от плеч свисают вниз, они трехпалые. От локтя левой руки горизонтально протянулся длинный шест (?), на котором через равные промежутки нанесены три пары 

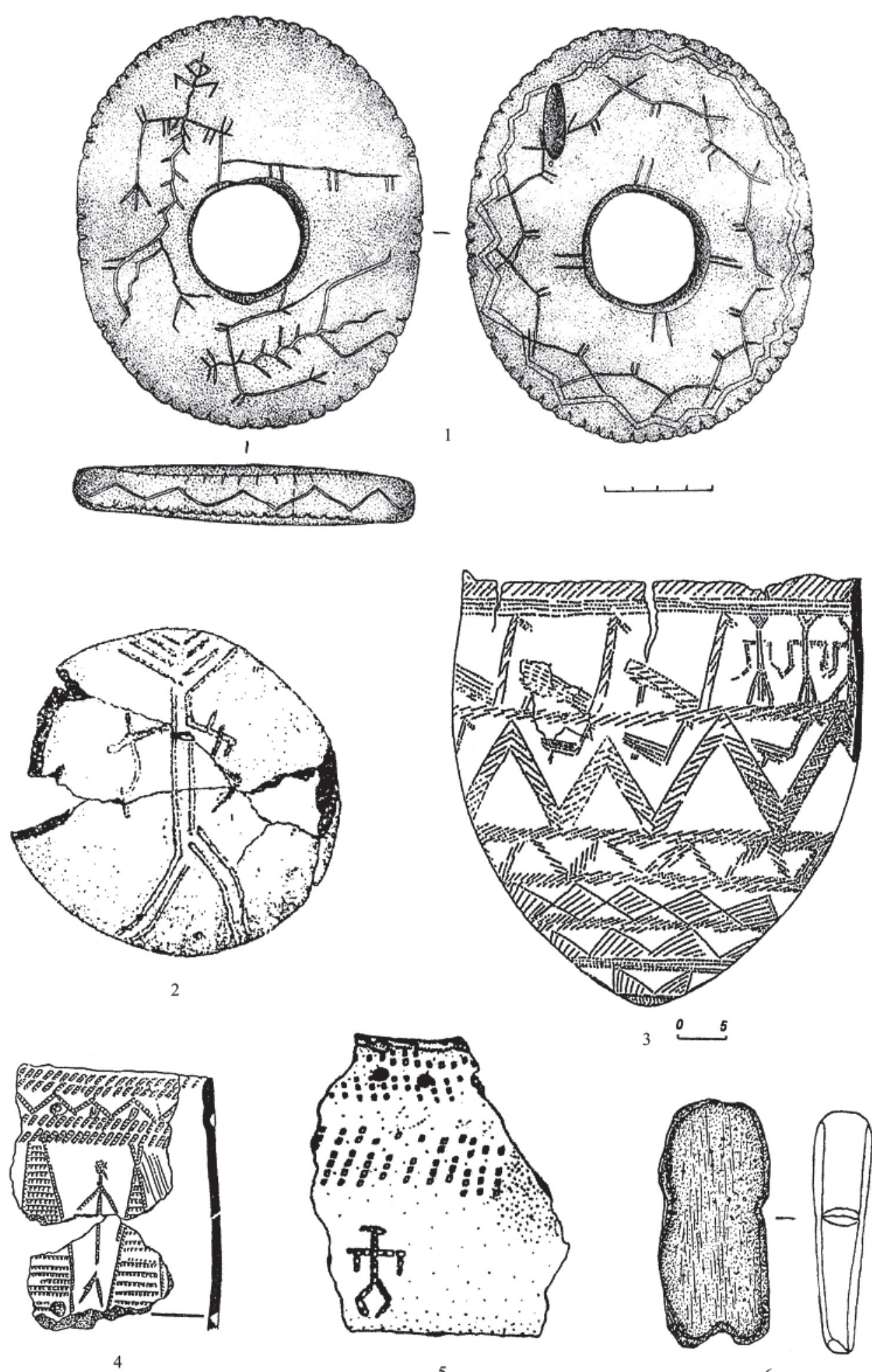

Рис. 3. Антропоморфные графические изображения на камне (1), на керамических сосудах (2-5) и каменная скульптура (6) (1 - Антоновск; 2 - Пикушка I; 3 - Палатки I; 4 - Боборыкино II; 5 - Лопью; 6 - Шайтанское озеро I)

насечек, обращенные вниз. На туловище восемь коротких рисок изображают, видимо, ребра. Одна нога, как и руки, трехпалая. Голова лежащей фигуры показана парными рисками, обращенными в разные стороны.
Плечи и руки у ней точно такие же, как и у первой фигуры. На туловище нанесено семь насечек (ребер), ноги не трехпалые, хвост обозначен зигзагом. Следует отметить, что все гравированные линии на лицевой и 
оборотной стороне предмета выполнены каменным орудием ${ }^{27}$.

Изображение обеих фигур настолько необычно, что их можно трактовать не только как ряженых людей (шаманов), но и как пресмыкающихся (ящеров, ящериц). Отдаленное сходство данные изображения имеют с антропоморфными фигурами, вырезанными на обратной стороне Большого Шигирского идола. Отдельные элементы гравированных геометрических узоров хорошо представлены в орнаментах на костяных мезолитических наконечниках стрел. Это зигзагообразные линии, зигзаги, на вершинах углов которых присутствуют парные насечки, а также зигзаги из отрезков, перекрещивающихся друг с другом ${ }^{28}$.

Ближайшие аналогии гравированным антропоморфам можно найти среди наскальных изображений Урала. На Ирбитском Писаном Камне присутствует фигура, у которой голова обозначена короткими отрезками, идущими под углом друг к другу, от широких плеч вниз свисают руки, на тулове короткими отростками изображены ребра $^{29}$. Еще более похожая антропоморфная фигура имеется на Писаном Камне на р. Тагил ${ }^{29}$. Тем не менее публикуемые изображения имеют лишь отдаленное сходство с приведенными аналогиями. Они своеобразны и оригинальны по исполнению и композиции. Можно предполагать, что обе фигуры изображают шаманов, облаченных в ритуальные костюмы человеко-зверя. Изображения шаманов в археологических материалах издавна привлекали внимание исследователей ${ }^{30}$. В последние годы интерес к данной теме усилился, и целая группа археологов занимается выделением шаманских изображений среди наскальных изображений Сибири (Окладников, 1948; Килуновская, 1999; Дэвлет М.А., Дэвлет Е.Г., 1999) $)^{31}$.

Утилитарное и сакральное назначение данного предмета требует специального исследования. Учитывая количество насечек на гранях диска, можно допустить, что он являлся своеобразным календарем и служил для фиксации и определения разнообразных астрономических явлений. Детальная расшифровка астрономических значений диска как древнего календаря приведена в работе А.А. Герасименко ${ }^{32}$.

По мнению уральских археологов, навершие можно датировать эпохой энеолита. Если учесть, что гравировки на предмете выполнены каменным и металлическим орудиями, это предположение выглядит вполне обоснованным. Косвенным свидетельством в пользу энеолитического возраста является и находка подобного диска с гравировкой в энеолитическом комплексе поселения Шувакиш I (озеро Шувакиш в окрестностях г. Екатеринбург $)^{33}$. K тому же во время выставки, приуроченной к семинару по проблемам изучения аятской культуры (Нижний Тагил, 2003 г.), выяснилось что оба диска - из Антоновска и Шувакиша - изготовлены из абсолютно идентичного минерала.

Заключают коллекцию антропоморфных изображений графические фигуры человека на керамической посуде. Самым известным изображением является антропоморфная фигура на неолитическом сосуде с поселения Пикушка I (Курганская обл.) (рис. 3, 2). Два неполных антропоморфных изображения на неолитических сосудах выявлены на Андреевском озере (ЮАО-IX и XII).

Традиция изображать антропоморфные фигуры на керамической посуде сохраняется и в энеолите. Уникальный сосуд с фигурными графическими изображениями антропоморфов и птиц обнаружен в энеолитическом комплексе памятника Палатки I. Верхний фриз сосуда украшен изображениями водоплавающих птиц и антропоморфных фигур. Три фигуры людей выполнены двойными линиями отпечатков гребенчатого штампа. Ноги у них расставлены, линии между ногами, возможно, изображают хвост. Руки у фигур опущены вниз и разведены в стороны (рис. 3, 3). Головы, как и на сосуде с Пикушек I, изображены углами. По мнению автора, эти углы обозначают пышный головной убор. Но В.Д. Викторова счи- 
тает их рогами ${ }^{34}$. В целом этот сюжет из трех антропоморфных фигур можно рассматривать как изображение танцующих ряженых в ритуальные одежды людей (шаманов).

На стоянке Бараний Мыс обнаружен неполный развал энеолитического сосуда, на котором кроме изображений косуль присутствует фигура человека ${ }^{35}$. Она выполнена гребенчатым штампом: туловище изображено тремя линиями, расставленные ноги - двумя, а согнутые и упирающиеся в поясницу руки - одной. К сожалению, и в этом случае голова на фрагменте сосуда отбита (намеренно?). Согнутая нога и упирающиеся в бедра руки позволяют и в этой фигуре видеть изображение танцующего человека.

Еще один энеолитический сосуд с изображением антропоморфных фигур происходит с поселения Боборыкино II (Курганская обл.). В верхней части сосуда расположен фриз с изображением человеческих фигур, которые чередуются с сильно вытянутыми заштрихованными треугольниками (возможно, изображениями жилищ). Фигуры выполнены оттисками гребенчатого штампа, изображены в фас с расставленными ногами и разведенными в стороны руками. Маленькая голова показана мелкими линиями и точками, повернута вправо. Уходящий вниз отросток, возможно, изображает бороду ${ }^{36}$ (рис. 3, 4).

K раннему бронзовому веку относится изображение «пляшущего человечка» на фрагменте сосуда со стоянки Лопью (Республика Коми). Одиночное изображение нанесено гребенчатым штампом в верхней части сосуда (рис. 3, 5). Антропоморфная фигурка изображена с расставленными и согнутыми в коленях ногами. Руки у нее разведены и согнуты в локтях. Фигура действительно похожа на танцующего человека ${ }^{37}$.

Таким образом, в настоящее время на территории Урала и прилегающего к нему Зауралья в литературе описано около 400 изображений живых существ, датируемых от палеолита до бронзового века. К ним относятся скульптуры из камня, кости, дерева, а также гравированные изображения на камне, кости и керамических сосудах. Среди них преобладают изображения животных. Антропоморфные фигуры представлены 60 изображениями. Это всего около $15 \%$.

\section{ПРИМЕЧАНИЯ}

${ }^{1}$ Котов В.Г. Изобразительная практика на основе естественных форм в палеолите Урала // Вестник археологии, антропологии и этнографии. 2018. № 1 (40). С. 16-27.

${ }^{2}$ Калинина И.В. Мезолитический субстрат в орнаментальной традиции обских угров // Миф, обряд и ритуальный предмет в древности. Екатеринбург - Сургут: Магеллан, 2007. С. 106-124.

${ }^{3}$ Панина С.Н. Культовые предметы в собрании археологических коллекций Свердловского областного краеведческого музея // Культовые памятники горно-лесного Урала. Екатеринбург: УрО РАН, 2004. С. 255-256.

${ }^{4}$ Сериков Ю.Б. Произведения искусства с культового центра на Шайтанском озере // Памятники археологии и художественное творчество: Материалы осеннего коллоквиума (с международным участием). Омск: ОмГПУ, 2004. С. 18-21.

${ }^{5}$ Матвеева Н.П. Антропоморфные фигурки из раскопок у Андреевского озера // Советская археология. 1985. № 2. С. 223-224.

${ }^{6}$ Необычное коллективное погребение эпохи неолита в Кумышанской пещере (Средний Урал) // Вестник археологии, антропологии и этнографии. 2013. № 2 (21). С. 4-10.

${ }^{7}$ Иванов С.В. Скульптура народов севера Сибири XIX - первой половины XX в. Л.: Наука, 1970. 296 c.

${ }^{8}$ Матюшин Г.Н. Энеолит Южного Урала. М.: Наука, 1982. 324 с.

9 Петрин В.T., Шорин А.Ф. Антропоморфная скульптура эпохи бронзы с Южного Урала // Советская археология. 1980. № 2. С. 226-228.

${ }^{10}$ Карманов В.Н. Мелкая пластика европейского Северо-Востока // Ученые записки Нижнетагильской государственной социально-педагогической академии. Общественные науки. Нижний Тагил: НТГСПА, 2006. С. 61-70.

${ }^{11}$ Сериков Ю.Б. Кремневая скульптура Урала (проблемы происхождения, хронологии и семантики) // Тверской археологический сборник. Вып. 7. Материалы 9-го - 11-го заседаний научно-методического семинара «Тверская земля и сопредельные территории в древности». Тверь: Триада, 2009. С. 391-410.

${ }^{12}$ Буров Г.М. Древний Синдор. М.: Наука, 1967. $220 \mathrm{c}$. 
${ }^{13}$ Карманов В.Н., Семенов В.А. Миниатюрная кремневая скульптура на памятниках Европейского Северо-Востока // Археология в пути или путь археолога. Часть 2. Археология в пути... СПб.: Санкт-Петербургское философское общество, 2001. С. 113-119.

${ }^{14}$ Сериков Ю.Б. О находках произведений искусства со стоянки Юрьино IV (Зауралье) // Советская археология. 1978. № 4. С. 245-248.

${ }^{15}$ Сериков Ю.Б. Шайтанское озеро - священное озеро древности. Нижний Тагил: НТГСПА, 2013. 408 с.

${ }^{16}$ Сериков Ю.Б. Галечные скульптуры - изобразительные символы обрядовой деятельности древнего человека // Миф и символ в прошлом и настоящем. Нижний Тагил: НТГСПА, 2007. C. 28-39.

${ }^{17}$ Сериков Ю.Б. Новые находки произведений мобильного искусства в Среднем Зауралье // Памятники археологии и художественное творчество: Материалы осеннего коллоквиума. Вып. 3. Омск: Издательский дом «Наука», 2005. С. 75-79.

${ }_{18}$ Обыденнов М.Ф., Корепанов К.И. Искусство Урала и Прикамья. Часть I. Эпоха камня и бронзы. Уфа: БЭК, 1997. 91 с.

${ }^{19}$ Раушенбах B.M. Женская статуэтка со стоянки Березовый мыс // МИА. Вып. 130. 1965. С. 65-68.

${ }^{20}$ Панина С.Н. Археологические исследования на Усть-Вагильском холме (2005-2006 гг.) // Вопросы археологии Урала. Вып. 25. Екатеринбург - Сургут: Магеллан, 2008. С. 137-146.

${ }^{21}$ Панина С.Н. Итоги полевых исследований Свердловского краеведческого музея (1977 - 1997) // III Берсовские чтения. Материалы научно-практической конференции. Екатеринбург: Банк культурной информации, 1999. C. 20-29.

${ }^{22}$ Викторова В.Д. Культовые озерные памятники // Культовые памятники горно-лесного Урала. Екатеринбург: УрО РАН, 2004. С. 144-157.

${ }^{23}$ Сериков Ю.Б. «Культ голов» в обрядовой практике древнего населения Урала // Охранные археологические исследования на Среднем Урале. Вып. 5. Екатеринбург: Банк культурной информации, 2007. С. 38-51.

${ }^{24}$ Сериков Ю.Б. Использование костей человека в ритуалах и культах древности // Тверской археологический сборник. Вып. 9. Материалы 13-го-15-го заседаний научно-методического семинара «Тверская земля и сопредельные территории в древности». Тверь: Триада, 2013. С. 23-30.

25 Чернецов В.Н. Представление о душе у обских угров // Исследования и материалы по вопро- сам первобытных религиозных верований. Труды Института этнографии. Т. 51. М., 1959. С. 114-156.

${ }^{26}$ Сериков Ю.Б. Каменное навершие с гравировками с восточного склона Среднего Урала // Вестник Сибирской Ассоциации Исследователей Первобытного искусства. Вып. 5. Кемерово, 2002. С. 31-33.

${ }^{27}$ Сериков Ю.Б. Гравировки по камню - редкий вид изобразительного искусства // Урало-Поволжье в древности и средневековье. Материалы Международной научной конференции V Халиковские чтения «Урало-Поволжье в древности и средневековье», посвященной 80-летию А.Х. Халикова. Серия «Археология евразийских степей». Выпуск 11. Казань: Фолиант, 2011. С. 203-221.

${ }^{28}$ Сериков Ю.Б. Орнаментированные наконечники стрел эпохи мезолита с пещерного святилища на Камне Дыроватом (р. Чусовая) // Материалы международной конференции «Каменный век европейских равнин: объекты из органических материалов и структура поселений как отражение человеческой культуры». Сергиев Посад: Подкова, 2001. С. 153-160.

29 Чернецов B.Н. Наскальные изображения Урала. М.: Наука, 1971. 120 с.

${ }^{30}$ Спицыын А.А. Шаманские изображения // Записки отделения Русской и Славянской археологии Российского Археологического общества. Т. 8. Вып. 1. СПб., 1906. С. 29-145.

${ }^{31}$ Окладников А.П. Древние шаманские изображения из Восточной Сибири // Советская археология. Т. Х. 1948. С. 203 - 225; Дэвлет М.А., Дэвлет Е.Г. Изображения шаманов в наскальном искусстве // 60 лет кафедре археологии МГу им. М.В. Ломоносова. Тезисы докладов юбилейной конференции, посвященной 60-летию кафедры археологии исторического факультета МГУ им. М.В. Ломоносова. М. МГУ, 1999. С. 86-89; Килуновская М.Е. Шаманистические мотивы в наскальном искусстве народов Саяно-Алтайского нагорья // Международная конференция по первобытному искусству. Труды. Т. 1. Кемерово: НИКАЛС, 1999. С. 232-238.

32 Герасименко A.A. Древний календарь и календарная мифология населения Среднего Зауралья (опыт интерпретации одной находки) // Четвертые Берсовские чтения. Екатеринбург: АКВА-ПРЕСС, 2004. С. 83-90.

33 Чаиркина Н.M. Энеолит Среднего Зауралья. Екатеринбург: УрО РАН, 2005. 313 с.

${ }^{34}$ Викторова В.Д., Колмакова В.В., Федорова А.Ю. И разные народы побывали здесь... // Образы и сакральное пространство древних эпох. Ека- 
теринбург: Аква-Пресс, 2003. С. 9-20.

35 Чаиркина Н.M. Антропо- и зооморфные образы энеолитических комплексов Среднего Зауралья // Вопросы археологии Урала. Вып. 23. Екатеринбург: УрГУ, 1998. С. 81-104.

${ }^{36}$ Сериков Ю.Б. Очерки по первобытному искусству Урала. Нижний Тагил: НТГСПА, 2014. 268 с.
${ }^{37}$ Буров Г.М. Археологическая разведка 1963 г. в зоне затопления будущего Усть-Куломского водохранилища // Древние поселения на Печоре и Вычегде. Отчеты о работах 1963 г. в зоне затопления Усть-Войского и Усть-Куломского водохранилищ. Сыктывкар: Коми книжное издательство, 1965. С. 139-159.

\title{
URALS ANTHROPOMORPHIC IMAGES IN STONE, CLAY AND ENGRAVINGS
}

\author{
(c) 2021 Yu.B. Serikov
}

\section{Russian State Vocational Pedagogical University (Nizhniy Tagil Branch)}

Despite its rarity, wooden sculpture of the Urals has been the subject of numerous publications and scientific researches. The anthropomorphic sculptures made of stone, clay, and engraved anthropomorphic images are less known. Currently, the literature describes about 400 images of living creatures found in the Urals and the adjacent Trans-Urals and dated in the time range from the Paleolithic to the Bronze Age. Anthropomorphic images are represented by 60 artifacts, which is only $15 \%$ of the total. Anthropomorphic stone images can be roughly divided into round, flat and flint sculptures. Pendants made in the form of a human head are very interesting. Clay figures are represented by images of women and separate heads. Anthropomorphic engraved images on stone and bone are rare finds. Images of anthropomorphic figures on ceramic vessels constitute a separate group. Most of the sculptural and graphic images dates back to the Neolithic and the Eneolithic.

Keywords: Urals, Stone Age, Bronze Age, anthropomorphic images, stone, clay, bone, engravings.

DOI: 10.37313/2658-4816-2021-3-4-90-101

Yuri Serikov, Doctor of History, Professor, Leading

Researcher.E-mail: u.b.serikov@mail.ru 